\title{
INHERITED EPIDERMOLYSIS BULLOSA: A CASE REPORT
}

\author{
Shyam Kumar Mahato ${ }^{1}$, Susana Lama², Nikhil Agarwal², Nagendra Chaudhary ${ }^{1}$
}

\begin{abstract}
Epidermolysis bullosa (EB) is a heterogeneous group of genetically determined, mechano-bullous disorders characterized by blister formation in response to mechanical trauma. The blistering of the skin occurs in the varying degrees of severity and can severely incapacitate the life of the afflicted patient. Epidermolysis Bullosa Simplex (EBS), the most commonly occurring type, is dominantly inherited where treatment still remains a major challenge. We report a newborn female with blistering of the skin during the immediate neonatal period.
\end{abstract}

KEY WORDS: Blistering disorders; Epidermolysis bullosa simplex; Hereditary; Mechanobullous

1. Assistant Professor, Department of Pediatrics, Universal College of Medical Sciences \& Teaching Hospital, Bhairahawa, Nepal

2. Junior Resident, Department of Pediatrics, Universal College of Medical Sciences \& Teaching Hospital, Bhairahawa, Nepal

\author{
For Correspondence \\ Dr. Nagendra Chaudhary \\ Department of Pediatrics, \\ Universal College of Medical Sciences \\ \& Teaching Hospital, \\ Bhairahawa, Nepal \\ E-mail: enagendra@hotmail.com
}




\section{INTRODUCTION}

Epidermolysis bullosa (EB) consists of a group of hereditary skin disorders characterized by formation of skin blisters and ulcers following minor skin trauma ${ }^{1}$. As the areas of the body most often affected in EB are sites subjected to frequent pressure or friction, it is also known as mechano-bullous disorder ${ }^{2}$.There are mainly 4 major types of EB disorders: Epidermolysis bullosa simplex (EBS), junctional epidermolysis bullosa, dystrophic epidermolysis bullosa and kindler syndrome ${ }^{3}$ where EBS is the most commonly occurring type with blisters usually presenting at birth or during the neonatal period ${ }^{4}$.

\section{CASE REPORT}

A single, term, female baby, small for gestational age, product of non-consanguineous marriage, no antenatal and natal complications, delivered to a multiparous Rh-negative mother by normal vaginal delivery, cried immediately after birth, with birth weight of $2340 \mathrm{~g}$ was admitted to neonatal intensive care unit (NICU) of tertiary care hospital (Western Nepal). Baby was put on breast feeding within 30 minutes of birth. Baby had reddish discoloration of limbs (Fig: 1) with skin peeling noticed at birth. During the hospital stay, the baby developed new blisters over limbs and trunk which ruptured spontaneously along with skin peeling (Fig: $2 \& 3$ ) and reddish discoloration. Parents gave a history of similar events occurring in three previous siblings, out of which two were females and one male. All the siblings had expired with the first female at 3 months of age, the second female at one and half month and male baby at 1 month of age. On detailed examination of the present case, there was reddish discoloration seen on both legs, more on right than left, extending from knee up to the feet and sole and over the both hand extending up to fingers. Fresh skin lesions in the form of ruptured blisters were seen on the back, buttocks and nape of neck. Oral cavity, conjunctiva, cornea, nails, scalp and genitalia were normal. Systemic examination was within normal limits.

A diagnosis of Epidermolysis bullosa simplex was made clinically. Skin biopsy was planned but could not be done due to parent's refusal. Baby was managed conservatively and nursed on thick/soft foam pad to prevent trauma inducing new blister formation. Baby was stable and doing well except that there was appearance of new skin lesions mainly at back and buttocks. The parents were explained about the baby's condition. The baby was discharged on day 3 on parents' request who succumbed on day 15 of life at home.

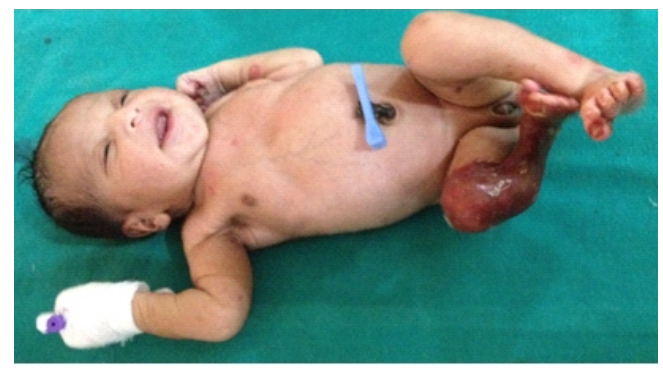

Figure 1: EBS with reddish raw area on right leg

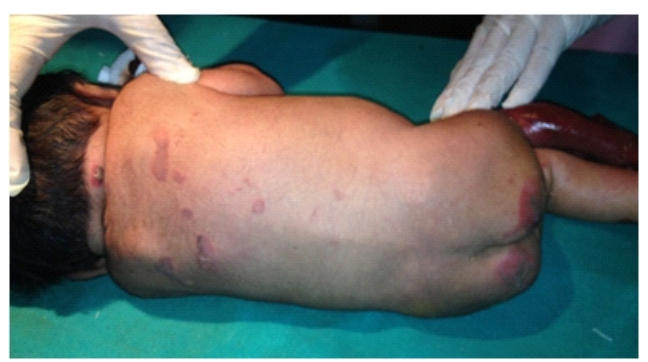

Figure 2: EBS with new lesions on neck, back and buttocks (pressure sites)

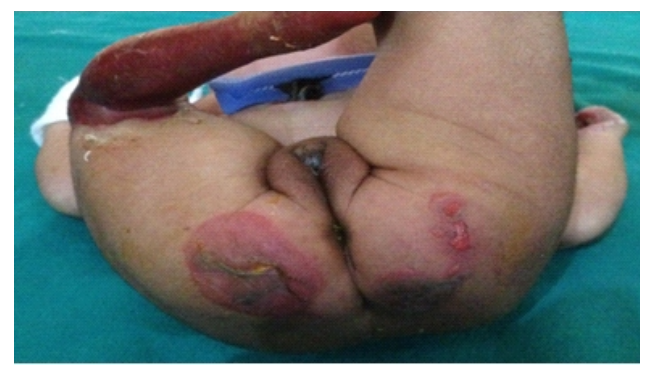

Figure 3: Ruptured blisters on buttocks with raw areas

\section{DISCUSSION}

Inherited EB encompasses over 30 phenotypically or geno typically distinct entities which share a common feature of mechanical fragility of epithelial lined or surfaced tissues, most notably the skin. These disorders represent heterogeneous phenotypes from localized skin fragility to neonatal death. A characteristic feature of all types of EB is the presence of recurrent blistering or erosions on minor traction to these tissues. The reported incidence is approximately 1 in 17000 live births with an estimated 500000 cases worldwide ${ }^{5}$. However, in many countries, the actual percentage of children born with EB is unknown ${ }^{2}$. EB has not been reported 
from Nepal so far to the best of our knowledge. Incidence is not affected by race or ethnic group ${ }^{6}$, and the disease affects both sexes equally.

There are 4 major types of inherited EB, differ not only phenotypically and genotypically but also by the site of ultrastructural disruption or cleavage. ${ }^{7-8}$

\section{Table 1: Classification of EB}

\begin{tabular}{|l|l|c|c|}
\hline \multicolumn{1}{|c|}{ Major EB type } & Level of Blister formation & Level of skin cleavage & $\begin{array}{c}\text { Known targeted } \\
\text { antigen/protein(s) }\end{array}$ \\
\hline EB Simplex & Intraepidermal & $\begin{array}{l}\text { Subcorneal/(suprabasal/mid- } \\
\text { epidermis("epidermolytic") }\end{array}$ & Keratins 5 and 14 \\
\hline Junctional EB & Intra-lamina lucida & $\begin{array}{l}\text { Intra-lamina lucida("lamina } \\
\text { lucidolytic") }\end{array}$ & $\begin{array}{l}\text { Laminin-332, type XVII } \\
\text { collagen }\end{array}$ \\
\hline Dystrophic EB & Sub-lamina densa & $\begin{array}{c}\text { Sub-lamina } \\
\text { densa("dermolytic") }\end{array}$ & Type VII collagen \\
\hline Kindler syndrome & $\begin{array}{l}\text { Multiple levels (Intra-lamina } \\
\text { lucida and sub-lamina densa) }\end{array}$ & Mixed & Kindlin-1 \\
\hline
\end{tabular}

Inherited EB is transmitted as either an autosomal dominant or autosomal recessive disease, depending on EB type and subtype. ${ }^{9}$ Mutations and change in targeted proteins/antigens in various types of EB has been mentioned in table $1 .^{9-11}$

The hallmark cutaneous features of inherited EB, in addition to mechanically fragile skin and easy inducibility of blisters or erosions at birth or neonatal period, may be the presence of milia, nail dystrophy, and scarring (usually atrophic). Other findings include exuberant granulation tissue (periorificial, axillary vaults, nape of the neck, lumbosacral spine, periungual and proximal nail folds), localized or confluent keratoderma of the palms and soles, and dyspigmentation (postinflammatory hypo- or hyperpigmentation, mottled or reticulate hyperpigmentation). Rarely, decreased or absent hair, albopapuloid lesions (flesh-colored or hypopigmented papules, usually arising on the lower trunk), and hypo- or hyperhidrosis are seen. The presence or absence of one or more findings may be age-dependent. Common sites of blisters are hands, feet, elbows, knees, legs and scalp. ${ }^{5}$ This is similar in this case in which hands and feet were predominantly affected. EBS blisters typically heal with minimal to no scar and do not result in skin atrophy. Secondary infection is the primary complication and the cause of death is resulting septicemia.

The diagnosis of EB is mainly clinical and confirmed by genetic analysis of the patient and the parents to definitively determine the mode of inheritance. ${ }^{12}$ Skin biopsy and immunofluorescence mapping is a useful diagnostic tool to determine the plane of separation and to identify the protein affected in each case. ${ }^{13}$ The protein affected in a specific case can be identified by analyzing the expression and distribution of antibodies to laminin-332 (formerly known as laminin-5), collagen VII, collagen XVII, plectin, a6b4 integrin, and keratin $14 .{ }^{14}$ In present case, biopsy was not consented and facilities for genetic studies were not available with us. Antenatal diagnosis is also possible. ${ }^{15-17}$

There is presently no definitive cure for EB. The objective of treatment is to alleviate symptoms and provide supportive measures. Therapy is therefore focused on the prevention of lesions and complications which requires multidisciplinary approach involving pediatrician, dermatologist, surgeon, nutritionist, dentist, physiotherapist, nurse, psychologist, pain specialist, and geneticist. ${ }^{18}$ Psychological support for parents and family members is vital. EB is not a contraindication for any vaccination. ${ }^{14}$ The presence of multiple wounds of varying duration and ability to heal makes management of EB difficult and complex. The babies with EB should be given expert nursing care on thick foam pads which protect them from undue trauma induced blister formation. Special precautions need to be taken for older children in the use of adhesive tapes, sphygmomanometer cuffs, tourniquets and other instruments that cause shearing of skin or mucous membranes. ${ }^{19}$ The erosions should be cleaned with sterile normal saline and covered with dressing pads or vaseline impregnated gauze. Topical antibiotics should not be applied to prevent development of antibiotic resistant bacteria. Oral and dental care should be kept in consideration as tooth eruption starts. Psychological support for parents and family members is vital .$^{14}$ Nutritional support is important for adequate growth and development and to help in optimal wound healing. Parents should be advised about prevention of trauma and occurrences of new lesions. ${ }^{3}$

\section{CONSENT}

Verbal consent was taken from the parents.

\section{REFERENCES}

1. Valari MD, Phillips RJ, Lake BD, Harper JI. Junctional epidermolysis bullosa and pyloric atresia: a distinct entity. Clinical and pathological studies in five patients. BrJ Dermatol. 1995 Nov;133(5):7326. http://dx.doi.org/10.1016/09269959(95)96072-g 
2. Salas-Alanis JC, McGrath JA. [2470insG, represents the commonest mutation in Mexican patients with dystrophic bullous epidermolysis. A study of 21 families]. Gac Médica México. 2006 Feb;142(1):2934. PMid:16548289

3. Cooper TW, Bauer EA. Epidermolysis bullosa: a review. Pediatr Dermatol. 1984 Jan;1(3):1818.

http://dx.doi.org/10.1111/j.1525-1470.1984.tb01113.x, PMid:6387664

4. Alper JC, Baden HP, Goldsmith LA. Kindler's syndrome. Arch Dermatol. 1978 Mar;114(3):457. http://dx.doi.org/10.1001/archderm.114.3.457, PMid:629586

5. Featherstone C. Epidermolysis bullosa: from fundamental molecular biology to clinical therapies. J Invest Dermatol. 2007 Feb;127(2):2569.

http://dx.doi.org/10.1038/sj.jid.5700731, PMid:17228301

6. Uitto J, Pulkkinen L. Epidermolysis bullosa in Mexico. Int $J$ Dermatol. 2000 Jun;39(6):4335.

http://dx.doi.org/10.1046/j.1365-4362.2000.00998.x, PMid:10944087

7. Price-Douglas W, Diehl-Svrjcek B. Epidermolysis bullosa: a case study in transport, treatment, and care. Adv Neonatal Care Off J Natl Assoc Neonatal Nurses. 2007 Dec;7(6):28994. http://dx.doi.org/10.1097/01.ANC.0000304967.46708.ea, PMid:18097210

8. Fine J-D. Inherited epidermolysis bullosa. Orphanet J Rare Dis. 2010:5:12.

http://dx.doi.org/10.1186/1750-1172-5-12,

PMCid:PMC2958369

9. Fine J-D, Eady RAJ, Bauer EA, Bauer JW, Bruckner-Tuderman $L$, Heagerty $A$, et al. The classification of inherited epidermolysis bullosa (EB): Report of the Third International Consensus Meeting on Diagnosis and Classification of EB. J Am Acad Dermatol. 2008 Jun;58(6):93150.

http://dx.doi.org/10.1016/j.jaad.2008.02.004, PMid:18374450

10. McGrath JA, McMillan JR, Dunnill MG, Pulkkinen L, Christiano AM, Rodeck CH, et al. Genetic basis of lethal junctional epidermolysis bullosa in an affected fetus: implications for prenatal diagnosis in one family. Prenat Diagn. $1995 \mathrm{Jul} ; 15(7): 64754$.

http://dx.doi.org/10.1002/pd.1970150710, PMid:8532625

11. Siegel DH, Ashton GHS, Penagos HG, Lee JV, Feiler HS, Wilhelmsen KC, et al. Loss of kindlin-1, a human homolog of the Caenorhabditis elegans actin-extracellular-matrix linker protein UNC-112, causes Kindler syndrome. Am J Hum Genet. $2003 \mathrm{Jul} ; 73(1): 17487$.

http://dx.doi.org/10.1086/376609, PMid:12789646

PMCid:PMC1180579
12. Trent JT, Kirsner RS. Epidermolysis bullosa: identification and treatment. Adv Skin Wound Care. 2003 Nov;16(6):28490. http://dx.doi.org/10.1097/00129334-200311000-00009, PMid:14652513

13. Solovan $C$, Ciolan M, Olariu L. The biomolecular and ultrastructural basis of epidermolysis bullosa. Acta Dermatovenerol Alp Pannonica Adriat. 2005

Dec;14(4):12735.14. Sia-ez-González C, Pezoa-Jares R, SalasAlanis JC. [Congenital epidermolysis bullosa: a review]. Actas Dermo-Sifiliográficas. 2009 Dec;100(10):84256. PMid:20038360

15. Das BB, Sahoo S. Dystrophic epidermolysis bullosa. J Perinatol Off J Calif Perinat Assoc. 2004 Jan;24(1):417. http://dx.doi.org/10.1038/sj.jp.7211019, PMid:14726937

16. Fassihi H, Eady R a. J, Mellerio JE, Ashton GHS, DoppingHepenstal PJC, Denyer JE, et al. Prenatal diagnosis for severe inherited skin disorders: 25 years' experience. Br J Dermatol. 2006 Jan;154(1):10613. http://dx.doi.org/10.1111/j.13652133.2005.07012.x, PMid:16403102

17. Wessagowit V, Chunharas A, Wattanasirichaigoon D, McGrath JA. Globalization of DNA-based prenatal diagnosis for recessive dystrophic epidermolysis bullosa. Clin Exp Dermatol. 2007 Nov;32(6):6879. http://dx.doi.org/10.1111/j.13652230.2007.02510.x, PMid:17868393

18. Fine J-D, Mellerio JE. Extracutaneous manifestations and complications of inherited epidermolysis bullosa: part $I$. Epithelial associated tissues. J Am Acad Dermatol. 2009 Sep;61(3):36784; quiz 3856. http://dx.doi.org/10.1016/j.jaad.2009.03.052 http://dx.doi.org/10.1016/j.jaad.2009.03.053

19. Sarkar R, Bansal S, Garg VK. Epidermolysis bullosa: where do we stand? Indian J Dermatol Venereol Leprol. 2011 Aug;77(4):4318. http://dx.doi.org/10.4103/0378-6323.82393 PMid:21727690 